Check for updates

Cite this: RSC Adv., 2017, 7, 42875

\title{
Generation of reactive cobalt oxo oxamate radical species for biomimetic oxidation of contaminants $\uparrow$
}

\begin{abstract}
Nan Li, (D) * Yun Zheng, Xuemei Jiang, Ran Zhang and Wenxing Chen*
The non-heme oxamate anionic cobalt(III) complexes [Co'II(opbaX)] $]^{-}$(opbaX $=4-\mathrm{X}$-ophenylenebis(oxamate), $\mathrm{X}=\mathrm{H}, \mathrm{NO}_{2}, \mathrm{CH}_{3}$ ) with different substituents were synthesized and applied to targeted micropollutant degradation. Typical radical scavengers (isopropanol and chlorine anions) have no negative effect on the catalytic oxidation of substrates, and no DMPO- ${ }^{\circ} \mathrm{OH}$ or DMPO- $\mathrm{OOH}$ (DMPO $=5,5$-dimethyl-pyrroline-oxide) signal was detected by electron paramagnetic resonance spin-trap technique in [Co'll'(opbaX) $]^{-} / \mathrm{H}_{2} \mathrm{O}_{2}$ system, suggesting that the non-hydroxyl radical biomimetic catalytic mechanism was dominant in the oxidation process. The results of high-definition ESI-MS pronounced the presence of cobalt-oxo intermediates which played a key role in the catalytic oxidation of substrates. Furthermore, density functional theory calculations were used to evaluate the viability of such cobaltoxo species and it demonstrated an optimizing electromer with a formulation of [CO $\left.{ }^{\mathrm{IV}}=\mathrm{O}^{*}\right]^{-}$or [CO ${ }^{\prime \prime \prime}-$ $\mathrm{OH}]^{*}$. The calculations explained that the catalytic activity of $\left[\mathrm{CO}^{\prime \prime \prime}(\mathrm{opbaX})\right]^{-}$was significantly enhanced by introducing an electron-withdrawing substituent which could change the coordination environment of cobalt to generate more electron-deficient cobalt-oxo species with stronger oxidizing power. This paper made a progress in verifying bio-mimic high oxidation state species and applied it to water purification, which provided deep insight into the properties of transition-metal centers in aqueous catalysis.
\end{abstract}

Received 27th July 2017
Accepted 30th August 2017

DOI: 10.1039/c7ra08317c

rsc.li/rsc-advances
In nature, bioenzymes like cytochrome $\mathrm{P} 450$ and horseradish peroxidase (HRP) utilizes $\mathrm{O}_{2}$ or $\mathrm{H}_{2} \mathrm{O}_{2}$ to convert recalcitrant compounds under mild conditions with unexpected catalytic activities. ${ }^{\mathbf{1 3 - 1 6}}$ However, these enzymes generate only in organisms and are perishable in practical application. So some researchers begin to distract their focus onto establishing artificial enzymes to imitate the essential and general principles of natural enzymes using stable and low-cost materials for a wide range of applications. It has been found that bioenzymes' selective oxidation of substrates attributes to the limited oxidation potential of high-valent metal-oxo active species. ${ }^{17}$ To date, Fe, Mn, Co, etc., metal complexes have been synthesized for bio-mimic targeted redoxes. ${ }^{18-20}$ For example, iron(III) porphyrin complexes can epoxide cyclohexene in protic solvent; ${ }^{21}$ and cobalt(III) complexes of bis- $N, N^{\prime}$-disubstituted oxamides are able to catalyze secondary alcohols to the corresponding ketones in acetonitrile and to epoxide olefin in fluorobenzene. ${ }^{22,23}$ However, successful applications of these selective catalysts to the global issue of serious water pollution have been seldom reported.

As known, P450 and HRP both work with the same $\mathrm{Fe}^{\mathrm{IV}}=\mathrm{O}$ active center in aqueous, while their different oxidant activation power may mainly attributed to the different electron nature of center Fe which is directly induced by the electronegativity of the fifth ligands and substituents on macrocyclic ligand. ${ }^{\mathbf{1 5 , 2 4 - 2 6}}$ Generally, the generation of high-valent metal-oxo active
National Engineering Lab for Textile Fiber Materials \& Processing Technology (Zhejiang), Zhejiang Sci-Tech University, Hangzhou 310018, China. E-mail: linan@ zstu.edu.cn;wxchen@zstu.edu.cn

$\dagger$ Electronic supplementary information (ESI) available. See DOI: $10.1039 / \mathrm{c} 7 \mathrm{ra08317c}$ 


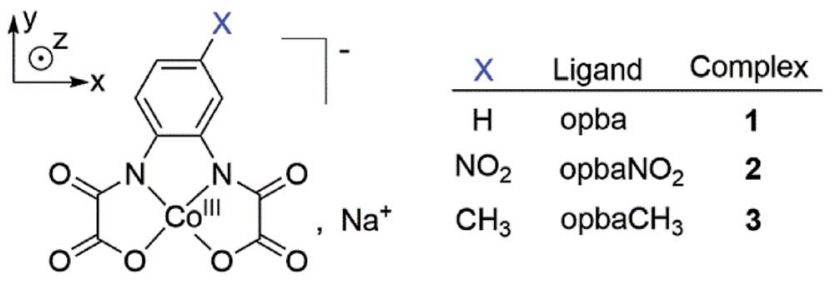

Scheme 1 The $\left[\mathrm{CO}^{\prime \prime \prime}(\mathrm{opbaX})\right]^{-}$activators used in this work.

species is determined by two competitive processes, heterolytic and homolytic cleavage of the $\mathrm{O}-\mathrm{O}$ bond. ${ }^{21,27}$ Based on this theory, the transformed $\mathrm{O}-\mathrm{O}$ bond cleavage has been achieved in the catalytic system with cobalt phthalocyanine through introducing axial fifth ligands in our previous studies, and the results indicated that the introduction of the fifth ligand changed the local environment around the cobalt cation and hence transformed the cleavage of peroxide $\mathrm{O}-\mathrm{O}$ from homolysis to heterolysis..$^{27,28}$ Here, we investigated the cleavage tendency of $\mathrm{O}-\mathrm{O}$ bond to see if it was possible to change the catalyst's oxidation power by introducing various substituents on benzene ring of Co macrocyclic ligand. Besides, few researchers have presented direct evidence proving the existence of cobalt-oxo active species, so it's necessary to focus on the depiction of the functioning active intermediates.

In this study, we synthesized square-planar phenylenebis(oxamate) (opba) cobalt(III) complexes with related ligand derivatives (Scheme 1) and emphasized $\mathrm{H}_{2} \mathrm{O}_{2}$ activation mechanism through analysing the possible electron transport and substituents' effects on the catalysis. The effect of environmental factors such as $\mathrm{pH}$, temperature, initial $\mathrm{H}_{2} \mathrm{O}_{2}$ carried out under mild conditions. The results of high-definition ESI-MS pronounced the presence of cobalt-oxo intermediates furthermore, the density functional theory calculations were used to evaluate the viability of such cobalt-oxo species and it demonstrated an optimizing electromer with a formulation of $\left[\mathrm{Co}^{\mathrm{IV}}=\mathrm{O}^{*}\right]^{-}$or $\left[\mathrm{CO}^{\mathrm{III}}-\mathrm{OH}\right]^{*}$. In conclusion, the biologically inspired subject addressed in this work illuminated cobalt-oxo active species in water and broadened the designing strategy for synthesizing novel bioenzyme alternatives for wider applications.

\section{Results and discussions}

\section{Characterization of cobalt complexes}

The square-planar cobalt(III) complexes anions, $\left[\mathrm{Co}^{\mathrm{III}}(\mathrm{opbaX})\right]^{-}$, were synthesized from the reaction between a Co(II) salt and the proligands in methanol solution by means of oxidizing the corresponding cobalt(II) complexes with dioxygen in situ. The solution state structure $\left[\mathrm{Co}^{\mathrm{III}}(\mathrm{opbaX})\right]^{-}$and the oxidation state of Co was identified by Synapt G2-S HDMS (ESI) and XPS. The accurate masses of anions $\left[\mathrm{Co}^{\mathrm{III}}(\mathrm{opbaX})\right]^{-}$and fragment ions were shown in Q-TOF MS and MS/MS spectra. In Q-TOF MS, this complex showed an ion at $m / z 306.9402$ (Fig. 1a), the mass was within $0.1 \mathrm{mDa}$ deviating the theoretical mass $(\mathrm{m} / \mathrm{z} 306.9401)$ for cobaltic complex anion $\left[\mathrm{Co}^{\mathrm{III}}(\mathrm{opba})\right]^{-}$rather than cobaltous

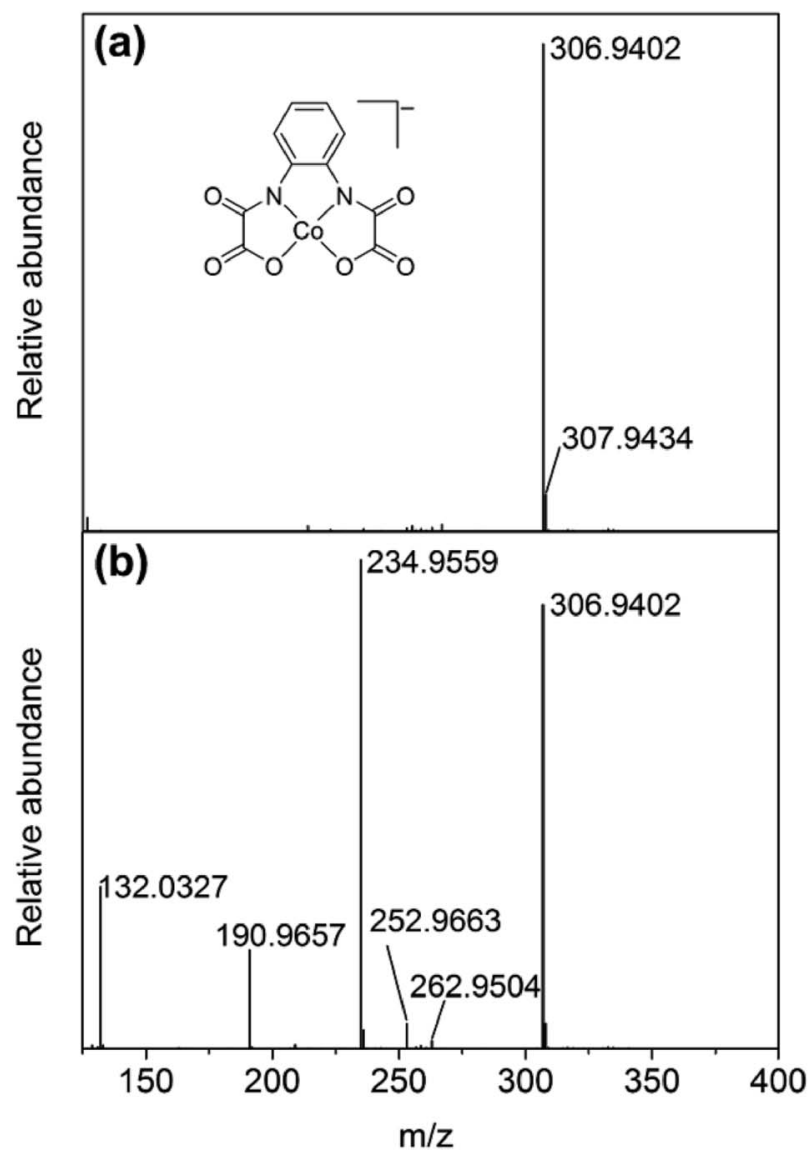

Fig. 1 Synapt G2-S HDMS (ESI) in negative mode of complex 1 in $\mathrm{MeCN}$ aqueous solution for (a) Q-TOF MS and (b) MS/MS.

complex dianion $\left(\left[\mathrm{Co}^{\mathrm{II}}(\mathrm{opba})\right]^{2-}, \mathrm{m} / z\right.$ 153.4701). Furthermore, the typical fragment ion masses were observed (see Fig. $1 \mathrm{~b}$ and Table S1 for ESI $\dagger$ ), which matched the theoretical masses within $0.5 \mathrm{mDa}$ error. Likewise, the accurate masses of methyl and nitro substituent cobalt complex anions and fragment ions conformed to the expectation of calculated value (Tables S2, S3 and Fig. S1, S2 see ESI $\dagger$ ).

Moreover, the oxidation state of Co in the complex is supported by XPS signals of the complex. The spin-orbit splitting of the Co2p level $(\Delta E)$ of complex $\mathbf{1}$ is shown in Fig. S3, $\dagger$ in which both the binding energy level splitting of Co2p1/2-Co2p3/2 $(\Delta E=$ $14.31 \mathrm{eV}$ ) and two weak satellite peaks demonstrated the generation of oxidation state $3+$ of $\mathrm{Co}$ in the surface region. ${ }^{29,30} \mathrm{We}$ guess that the strong electron-donating property of the $\mathrm{N}_{2}-\mathrm{O}_{2}$ coordination environment contributed to the generation of $\mathrm{Co}^{\mathrm{III}}{ }^{31}$

To further prove the chemical structure of our catalysts, ${ }^{1} \mathrm{H}$ NMR $\left(\mathrm{D}_{2} \mathrm{O}\right)$ spectra was employed. As shown in Fig. $\mathrm{S} 4, \uparrow$ the sharp singlet assigned at $\delta 2.23 \mathrm{ppm}$ was attributed to the $\mathrm{Ar}-$ methyl protons of complex $3 .^{32,33}$ In the spectra of complex 1, 2 and $\mathbf{3}$, the multiplets observed in the low field region were the characteristic of benzene ring protons, while chemical shift to higher and lower magnetic field are ascribed to the contribution of electron-withdrawing nitro and electron-donating methyl respectively. In conclusion, the result of LC-MS and ${ }^{1} \mathrm{H}$ NMR clearly described the chemical structure of our catalysts. 
Therefore, it's evident that the synthesized compounds correspond to cobaltic complex anions $\left[\mathrm{Co}^{\mathrm{III}}(\mathrm{opbaX})\right]^{-}$.

\section{Catalytic oxidation of C.I. acid red 1 (AR1) and $p$-chlorophenol}

In order to comparatively evaluate the effect of substituent ligands on the catalytic degradation of organic pollutants, the azo dye AR1 and $p$-chlorophenol (two typical aromatic pollutants) were selected as model substrates. As shown in Fig. 2, AR1 is barely degraded in the presence of the cobalt complexes alone (curve a-c, Fig. 2) and is the same when $\mathrm{H}_{2} \mathrm{O}_{2}$ is present alone (curve d, Fig. 2). When both the cobalt complex and $2 \mathrm{mM} \mathrm{H}_{2} \mathrm{O}_{2}$ was presented, the concentration of AR1 declined rapidly with increasing reaction time (curve e-g, Fig. 2) with an degradation rate order of $\left[\mathrm{Co}^{\mathrm{III}}\left(\mathrm{opbaNO}_{2}\right)\right]^{-}(\mathbf{2})>\left[\mathrm{Co}^{\mathrm{III}}(\mathrm{opba})\right]^{-}(\mathbf{1})>$ $\left[\mathrm{Co}^{\mathrm{III}}\left(\mathrm{opbaCH}_{3}\right)\right]^{-}(3)$. In addition, the catalytic elimination of $p$ chlorophenol was carried out, and the removal rate was around $48 \%, 57 \%$ and $2 \%$ in the first $10 \mathrm{~min}$ in the presence of complex $\mathbf{1}, 2$ and 3 respectively (Fig. S5 $\dagger$ ). Hence, we hypothesize a correlation between the catalytic activity and the electron donor capacity of ligands to account for the phenomenon: the electronwithdrawing nitro substituent promoted a higher effective positive charge at cobalt compared with electron-donating methyl substituent, which was analogous to the ligand effect on Fe(III)TAML (tetraamido macrocycle ligand) ${ }^{34}$ which indicated that the presence of electron-withdrawing substituent facilitated the generation of active intermediates..$^{21,35,36}$

\section{Effect of pH and temperature}

The investigation of $\mathrm{pH}$ and temperature effect on 1-catalyzed deposition of AR1 activated by $\mathrm{H}_{2} \mathrm{O}_{2}$ is shown in Fig. 3. Complex 1 can efficiently activate $\mathrm{H}_{2} \mathrm{O}_{2}$ in the range of alkalinity (pH 811) which is consistent with the environmental conditions. ${ }^{37}$ Moreover, AR1 removal in initial 10 min increased from 37.3\% to $83.6 \%$ as the temperature increased from 15 to $45{ }^{\circ} \mathrm{C}$ at pH 9.0 (Fig. 3a). An $E_{\text {a }}$ value of $34.61 \mathrm{KJ} \mathrm{mol}^{-1}$ was obtained by plotting $k_{\text {obs }}$ versus $1 / T$ (Fig. S6 $\dagger$ ). And the regression coefficient $\left(R^{2}\right)$ was close to 0.95 , which indicated that the degradation

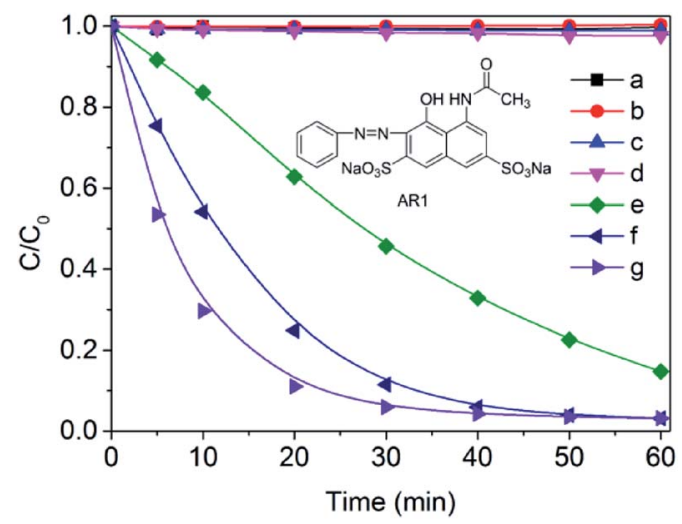

Fig. 2 Bleaching of AR1 (0.05 mM) under different conditions: (a) complex 3, (b) complex 1 and (c) complex 2 without $\mathrm{H}_{2} \mathrm{O}_{2}$; (d) $\mathrm{H}_{2} \mathrm{O}_{2}$; (e) complex 3, (f) complex 1 and (g) complex 2 with $\mathrm{H}_{2} \mathrm{O}_{2} ;\left[\mathrm{H}_{2} \mathrm{O}_{2}\right]=2 \mathrm{mM}$, [complexes 1-3] $=0.02 \mathrm{mM}, T=25^{\circ} \mathrm{C}, \mathrm{pH} 9.0$.
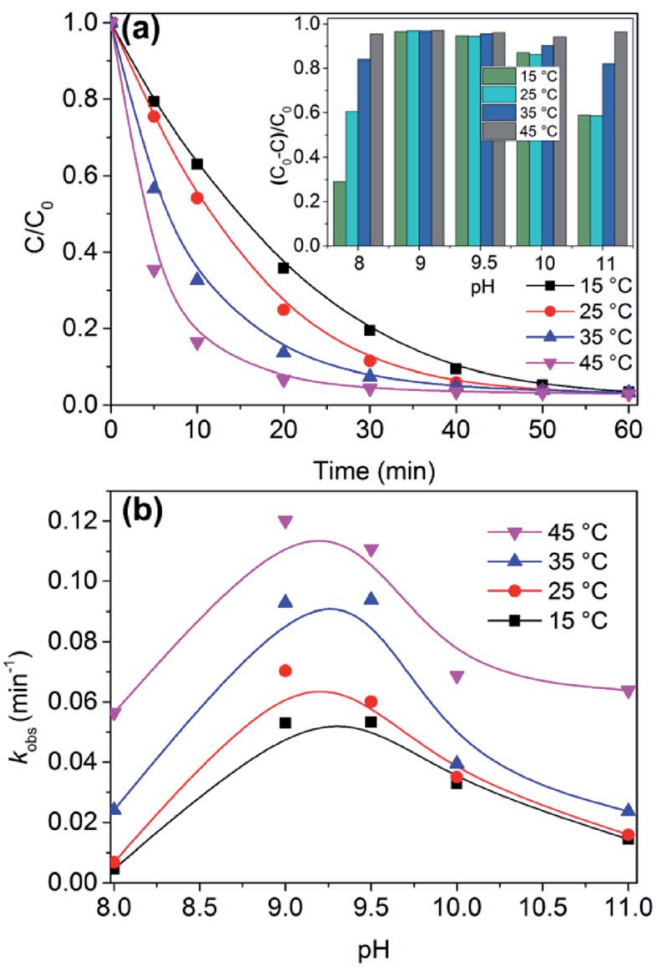

Fig. 3 (a) Effect of the temperature on catalyst oxidation of AR1 10.05 $\mathrm{mM}$ ) at $\mathrm{pH}$ 9.0; (b) effect of $\mathrm{pH}$ on the apparent rate constant $k_{\text {obs }}$ for the oxidation of AR1 by $\mathrm{H}_{2} \mathrm{O}_{2}$ catalyzed by 1 at different temperatures. The inset shows $\mathrm{pH}$ profiles of the removal rates of AR1 in the presence of 1 and $\mathrm{H}_{2} \mathrm{O}_{2}$ after reaction for $60 \mathrm{~min}$.

kinetics of AR1 decomposed by $1 / \mathrm{H}_{2} \mathrm{O}_{2}$ followed pseudo firstorder reaction kinetics well in the initial reaction stage where the concentration of $\mathrm{H}_{2} \mathrm{O}_{2}$ was enough. ${ }^{38}$ So we concluded that the decomposition of AR1 has less dependence on temperature from 15 to $45^{\circ} \mathrm{C}$ because of the relatively small value of $E_{\mathrm{a}}$ which could be easily achieved in comparison with ordinary thermal reactions. ${ }^{39}$

Furthermore, the pseudo-first-order rate constants $\left(k_{\mathrm{obs}}\right)$ increased at the beginning and then decreased with the increase of $\mathrm{pH}$ values, finally the maximum rates occur at $\mathrm{pH}$ 9.0-9.5 (Fig. 3b). Hence, the result showed that the catalytic reaction kinetics were affected significantly by $\mathrm{pH}$, which is interpreted as follows: the hydrolysis of the complex somewhat occurs and the dissociation of $\mathrm{H}_{2} \mathrm{O}_{2}$ was slower when $\mathrm{pH}$ moved toward neutral, which caused the limited coordination between $\mathrm{HOO}^{-}$and the central cobalt ions because the formation of active species was restrained. And when the $\mathrm{pH}$ of the solution was high, $\mathrm{HOO}^{-}$, the conjugate anion of $\mathrm{H}_{2} \mathrm{O}_{2}$, reacted with a non-dissociated molecule of $\mathrm{H}_{2} \mathrm{O}_{2}$ and ultimately resulted in the generation of oxygen and water. ${ }^{40,41}$

\section{Effect of $\mathrm{H}_{2} \mathrm{O}_{2}$ concentration}

The relationship between the degradation rate of AR1 and initial $\mathrm{H}_{2} \mathrm{O}_{2}$ concentrations were investigated and shown in Fig. S7, $\dagger$ which indicates that the AR1 can be effectively removed even at a very low concentration of $\mathrm{H}_{2} \mathrm{O}_{2}(0.5 \mathrm{mM})$, and 
even more than $90 \%$ of AR1 can be removed at such a low concentration of $\mathrm{H}_{2} \mathrm{O}_{2}$ in 1 hour. So this reaction system could significantly reduce the disproportionate amount of $\mathrm{H}_{2} \mathrm{O}_{2}$ that presented in some ${ }^{\circ} \mathrm{OH}$-involving reaction systems, because in high backgrounds of complicated background, ${ }^{\circ} \mathrm{OH}$ inevitably react with easily handled constituents or the free coordination catalysts in homogeneous system..$^{34,42}$

\section{Sustaining catalytic ability of the complexes}

One of the most significant distinguishes between bio-enzymes and artificial catalyst is stability. To checkout if the catalysts were durable in water purification, representative 1 was examined by subsequent additions of dye and $\mathrm{H}_{2} \mathrm{O}_{2}$ at $\mathrm{pH}$ 9.0. As seen in Fig. 4, the removal of AR1 after 60 min was about $96 \%$ by the end of the first cycle, after eight cycles with repeated additions of the same amount of original dye and 1/3 times as much as the original amount of $\mathrm{H}_{2} \mathrm{O}_{2}$, the removal rate of AR1 was still maintained at more than $90 \%$, which suggested that there existed no suicidal inactivation in our reaction system.

\section{Detection of active species}

As the oxidation mechanism of organic pollutants with $\mathrm{H}_{2} \mathrm{O}_{2}$ catalyzed by $\left[\mathrm{Co}^{\mathrm{III}}(\mathrm{opbaX})\right]^{-}$in aqueous solution has not been previously reported, it is necessary to present clear insights into the function mechanisms of these catalysts. As we know, $\mathrm{NaCl}$ is a prevailing accelerant widely used in the dye industry and plays a vital role in the dyeing process for the transfer of dye stuff to fabric. However, various studies reported the retardation effect of $\mathrm{NaCl}$ on degradation of pollutants especially on the $\mathrm{OH}$ mechanism. ${ }^{\mathbf{4 3 4}}$ Hence, it is important to evaluate the impact of inorganic salts on the catalytic oxidation systems. As expected, the degradation efficiency of $\mathbf{1}$ displayed no significant change in the presence of $\mathrm{NaCl}$ compared with the control experiment (Fig. 5). This meant that this catalytic system has potential and practical application value in treating salt-containing wastewater and that there were no free ${ }^{\circ} \mathrm{OH}$ generated in this system.

In order to investigate the intermediate active species which generate based on the cleavage of $\mathrm{O}-\mathrm{O}$ bond in hydrogen

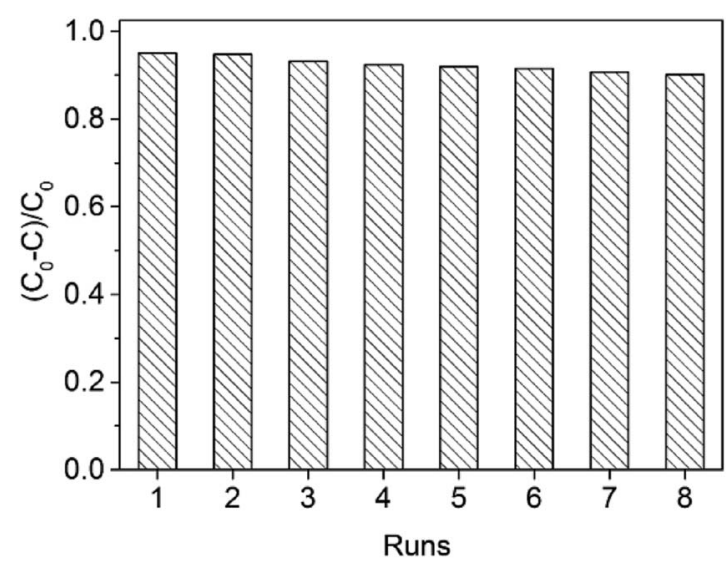

Fig. 4 Cyclic catalyst oxidation of AR1 (0.05 mM), [complex 1] = $0.02 \mathrm{mM},\left[\mathrm{H}_{2} \mathrm{O}_{2}\right]=2 \mathrm{mM}, \mathrm{T}=25^{\circ} \mathrm{C}, \mathrm{pH} 9.0$.

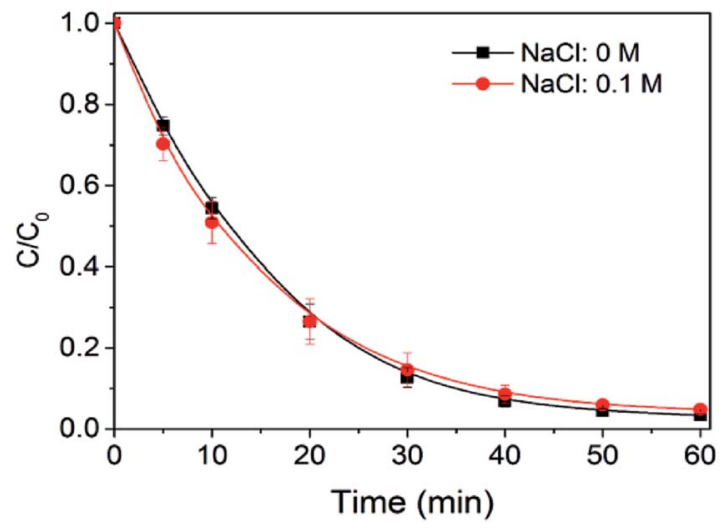

Fig. 5 Effect of $\mathrm{NaCl}$ on catalytic oxidation of $\mathrm{AR} 1(0.05 \mathrm{mM})$ in the presence of $1(0.02 \mathrm{mM})$ and $\mathrm{H}_{2} \mathrm{O}_{2}(2 \mathrm{mM}), \mathrm{T}=25^{\circ} \mathrm{C}, \mathrm{pH}$ 9.0. Error bars represent the standard error from three independent experiments.

peroxide, isopropanol (IPA), a typical ${ }^{\circ} \mathrm{OH}$ scavenger, ${ }^{45,46}$ was employed to determine whether ${ }^{\circ} \mathrm{OH}$ dominated the reactions or not. As a represent, the catalysis of $\mathbf{1}$ in the presence of IPA was carried out. As shown in Fig. 6a, the degradation rate of 1 presented in IPA (its concentration was 5000 times as 1) was significantly in good agreement with the control experiment, which favored the non-'OH mechanism. Moreover, EPR spin-trap technique (using DMPO (DMPO = 5,5-dimethyl-pyrroline-oxide) as the trapping reagent) was employed to detect the possibility that free radicals were produced in the reactions described above. ${ }^{47}$ As a result shown in Fig. 6b, no DMPO- ${ }^{-} \mathrm{OH}$ signal or other free radicals showed up, indicating that ${ }^{\circ} \mathrm{OH}$ did not form in the catalytic reaction, which supported the positive results of isopropanol and $\mathrm{NaCl}$ experiments. An additional experiment conducted in methanol solution was conducted to probe whether there were any superoxide radicals $\left({ }^{\circ} \mathrm{OOH}\right)$ generated during the reaction process. As shown in Fig. 6c, no DMPO-'OOH species were observed in $\mathbf{1} / \mathrm{H}_{2} \mathrm{O}_{2}$ system either, suggesting the catalytic mechanism belongs to non-hydroxyl radical pathway.

To obtain the evidence for the reactive intermediates, ESI-MS with a soft MS ionization technique, was employed for direct studies of catalytic intermediates, especially for the transient intermediates. ${ }^{48,49}$ The unsubstituted complex 1 was chosen for investigation and reacting with 2 equivalent $m$-chloroperbenzoic acid ( $\mathrm{mCPBA}$ ) playing as oxidant in the presence of trace $\mathrm{NH}_{3} \cdot \mathrm{H}_{2} \mathrm{O}$ at $-40{ }^{\circ} \mathrm{C}$ in $\mathrm{CH}_{3} \mathrm{CN}$. The prominent ions at a mass/charge $(\mathrm{m} / \mathrm{z})$ ratio of 322.9379 , as shown in Fig. 7 , with a mass corresponding exactly to the formulation of $[\mathrm{Co}(\mathrm{O})(\mathrm{opba})]^{-}$within $2.8 \mathrm{mDa}$ mass error. Hence, the electromer of high-valent cobalt-oxo $\left(\left[\mathrm{Co}^{\mathrm{IV}}=\mathrm{O}\right]^{-}\right.$or $\left.\left[\mathrm{Co}^{\mathrm{V}}=\mathrm{O}\right]^{-}\right)$and cobalt(III)-oxo ([Co $\left.\left.{ }^{\mathrm{III}}-\mathrm{OH}\right]\right)$ was presumed considering dehydrogenation of MS in the negative ion mode.

Illuminating the valence state of the activated species is imperative for the study of electron transmission pathway. DFT calculations of Gaussian 09 program with functional B3LYP and basis set $6-31 \mathrm{G}$ method is potent. ${ }^{50}$ Since the related intermediate spin $\mathrm{d}^{6}$ square-planar cobalt(III) complexes have previously been reported, the electron spin density distributions were calculated with $S=0, S=1, S=2 . .^{51}$ 

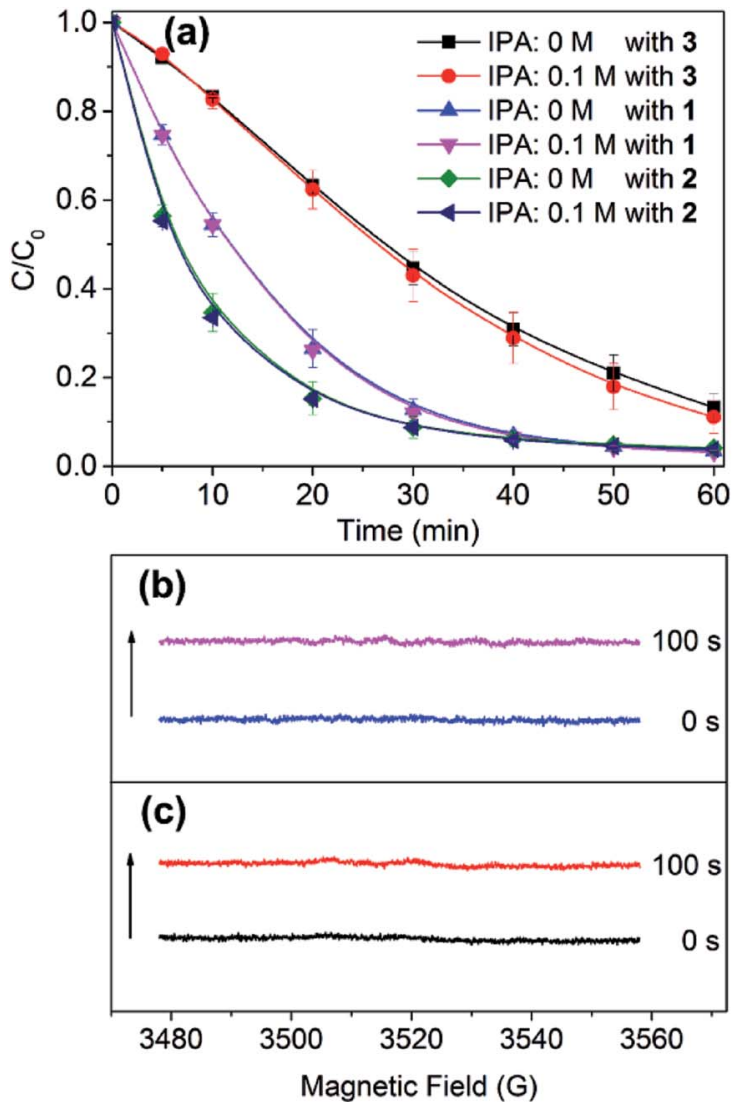

Fig. 6 (a) Concentration changes of AR1 $(0.05 \mathrm{mM})$ in the presence of complexes 1-3 with or without isopropanol. Error bars represent the standard error from three independent experiments; (b) DMPO spintrapping EPR spectra in AR1 $(0.05 \mathrm{mM})$ aqueous solution in the presence of complex 1 and $\mathrm{H}_{2} \mathrm{O}_{2}$ (2 mM) with DMPO (20 mM); (c) DMPO spin-trapping EPR spectra in AR1 $(0.05 \mathrm{mM})$ methanol solution in the presence of complex 1 and $\mathrm{H}_{2} \mathrm{O}_{2}(2 \mathrm{mM})$ with DMPO (20 mM).

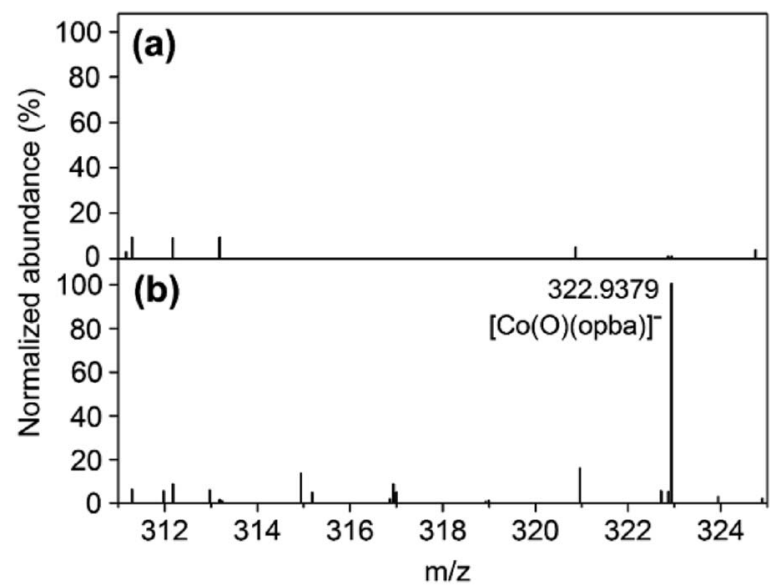

Fig. 7 (a) High-definition electrospray mass spectra of complex 1; (b) in the presence of 2 equivalents of $m C P B A$.

Firstly we calculated high-valent models $\left(\left[\mathrm{Co}^{\mathrm{IV}}=\mathrm{O}\right]^{-}\right.$or $\left.\left[\mathrm{Co}^{\mathrm{V}}=\mathrm{O}\right]^{-}\right)$and chose the triplet $(S=1)$ spin ground state because it possessed the lowest energy of the optimized structures (Table S4 $\dagger$ ) in which we calculated the intermediates by placing an oxygen atom near the optimized $\left[\mathrm{Co}^{\mathrm{III}}(\mathrm{opbaX})\right]^{-}$ (Tables S5 and S6 $\dagger$ ). According to the calculated results, we concluded that high-valent cobalt-oxo species formed with a $\mathrm{Co}=\mathrm{O}$ bond length order of $\left[\mathrm{Co}^{\mathrm{N}}(\mathrm{O})\left(\mathrm{opbaCH}_{3}\right)\right]^{-}>$ $\left[\mathrm{Co}^{\mathrm{N}}(\mathrm{O})(\mathrm{opba})\right]^{-}>\left[\mathrm{Co}^{\mathrm{N}}(\mathrm{O})\left(\text { opbaNO}_{2}\right)\right]^{-}$(Fig. 8, Tables S7-S9, $\dagger \mathrm{N}$ means the valence state of $\mathrm{Co}$ ). In addition, the electron density on Co was decreased by electron-withdrawing $-\mathrm{NO}_{2}$ and the electrophilicity of Co was increased, ${ }^{52}$ while the electrondonating $-\mathrm{CH}_{3}$ functioned inversely.

Moreover, a large unpaired electron spin density $(\sim 1$, neatly $50 \%$ of the total) located around the oxo moiety of $\mathrm{Co}=\mathrm{O}$, which meant there existed an unpaired electron on the oxo moiety (Tables S10-S12†). And the spin density on excited Co reduced (a)

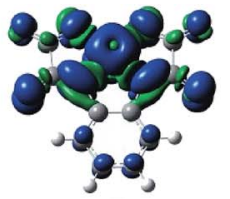

(c)

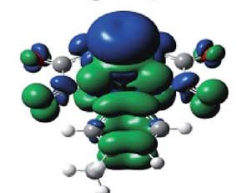

(e)

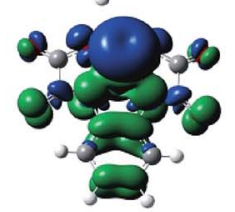

(g)

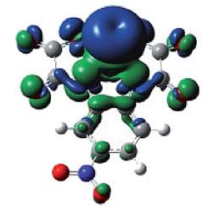

(i)

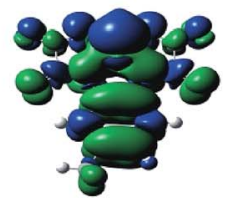

(k)

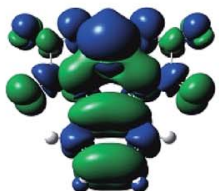

(m)

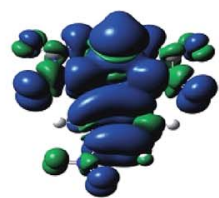

(b)

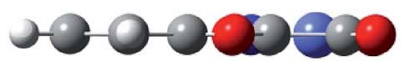

(d)
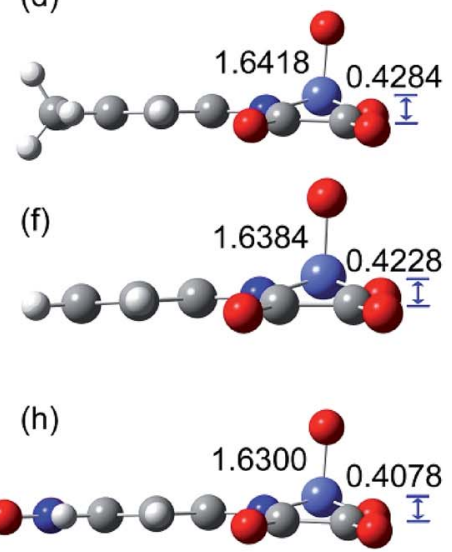

(j)

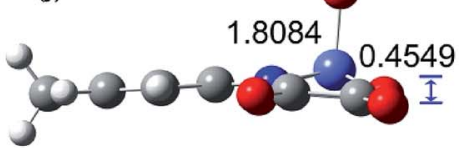

(l)

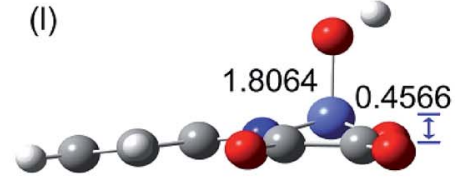

(n)

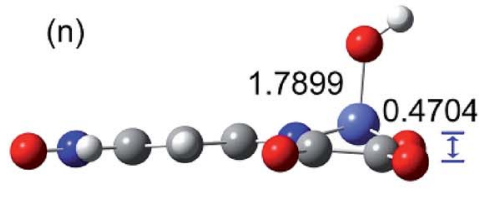

Fig. 8 Unpaired electron spin distribution and geometrically optimized structure of $\left[\mathrm{Co}^{\prime \prime \prime}(\mathrm{opba})\right]^{-}(\mathrm{a}, \mathrm{b}),\left[\mathrm{Co}(\mathrm{O})\left(\mathrm{opbaCH}_{3}\right)\right]^{-}(\mathrm{c}, \mathrm{d})$, $[\mathrm{Co}(\mathrm{O})(\mathrm{opba})]^{-}(\mathrm{e}, \mathrm{f}),\left[\mathrm{Co}(\mathrm{O})\left(\mathrm{opbaNO}_{2}\right)\right]^{-}(\mathrm{g}, \mathrm{h}), \mathrm{Co}(\mathrm{OH})\left(\mathrm{opbaCH}_{3}\right)(\mathrm{i}, \mathrm{j})$, $\mathrm{Co}(\mathrm{OH})(\mathrm{opba})(\mathrm{k}, \mathrm{l}), \mathrm{Co}(\mathrm{OH})\left(\mathrm{opbaNO} \mathrm{N}_{2}\right)(\mathrm{m}, \mathrm{n})$ based on DFT calculation. Red, oxygen; blue, nitrogen; purple, cobalt. Selected bond lengths $(\AA \AA)$ of Co-O and the deviation height $(\AA)$ of Co are given. 
to 1.24 compared with the data calculated for ground state $\left[\mathrm{Co}^{\mathrm{III}} \text { (opba) }\right]^{-}(\sim 1.8)$, which meant Co lost a d-electron for the coordination to $\mathrm{O}$ after the $\mathrm{O}-\mathrm{O}$ bond cleaved heterolytically. As a result, the $\mathrm{Co}^{\mathrm{III}}$ was oxidized to $\mathrm{Co}^{\mathrm{IV}}$. So the active intermediate can be described as $\left[\mathrm{Co}^{\mathrm{IV}}=\mathrm{O}^{\circ}\right]^{-}$species, like the radical species of $\mathrm{O}=\mathrm{Fe}^{\mathrm{IV}}-\mathrm{AcO}^{\circ}$ reported by Yong Wang et al. ${ }^{53}$ Furthermore, the $\mathrm{N}_{2} \mathrm{O}_{2}$-plane deviation of Co empowered $\mathrm{O}$ to accept electron via oxidizing the substrates, especially the $\left[{ }^{\circ} \mathrm{O}=\mathrm{Co}\left(\mathrm{opbaNO}_{2}\right)\right]^{-}$with a nitro substituent which has the shortest $\mathrm{N}_{2} \mathrm{O}_{2}$-plane deviation of Co $(0.4078 \AA)$.

To understand the origin of these properties, we have calculated the Frontier molecular orbitals (FMOs). According to the FMO theory, electrophiles require lowest unoccupied orbitals (LUMO) with high molecular orbital compositions on a reacting atom to achieve segistration with the FMOs on the nucleophilic substrate. ${ }^{54-56}$ In our calculations (Fig. 9a), LUMO and LUMO +1 of catalysts are mainly formed by the contributions of the $\mathrm{O}$ and Co d orbitals, which means the Co-O antibonding orbitals are the key FMOs; the $\mathrm{O}$ is the reacting atom, which interacts with the FMOs of the nucleophilic reagent. Moreover, the catalyst with the electron-donating methyl give highest energy levels of LUMO and singly occupied MO (SOMO), and that with electron-withdrawing cyano group has the lowest energy levels. The electron-withdrawing effect decreases the energy of LUMO intensively and the SOMO-LUMO gap is

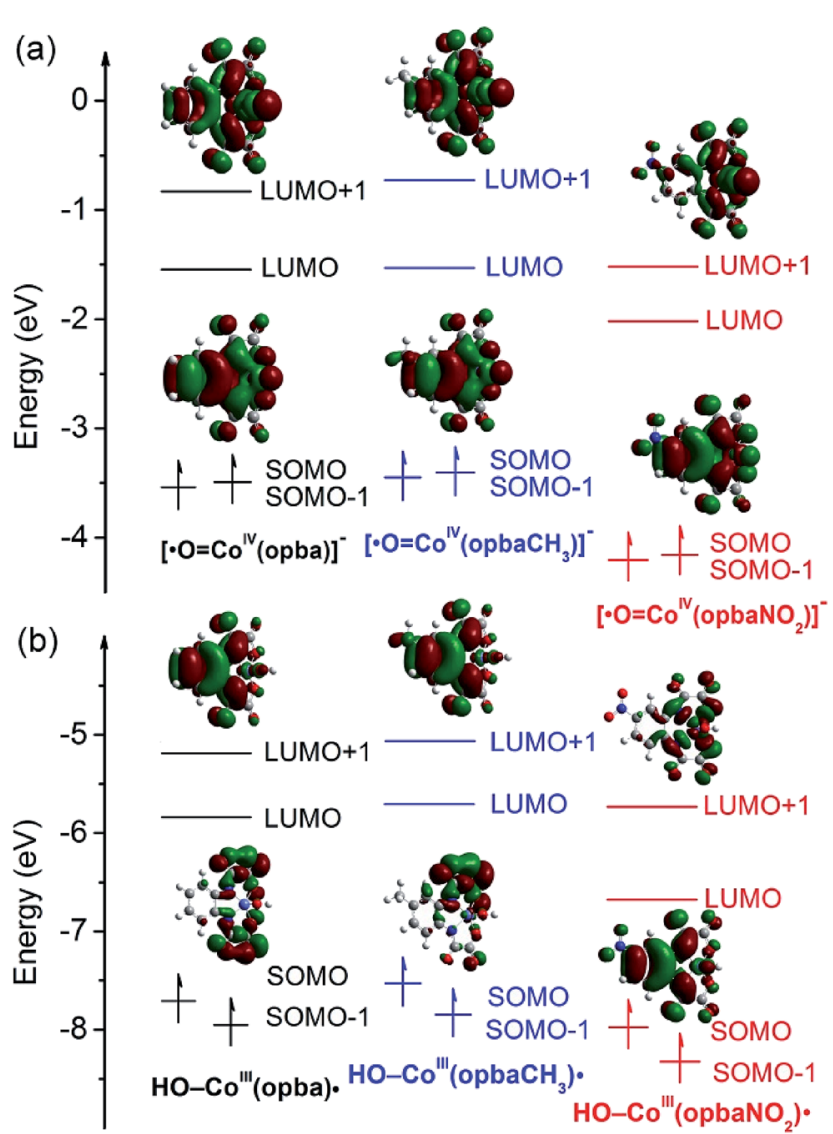

Fig. 9 Frontier molecular orbitals energy level and molecular orbitals of $\left[\mathrm{CO}^{\mathrm{IV}}=\mathrm{O}^{*}\right]^{-}$and $\left[\mathrm{CO}^{\prime \prime \prime}-\mathrm{OH}\right]^{*}$. enhanced, which indicates that $\mathbf{3}$ might be more susceptible to oxidants after substituted by electron-withdrawing substituent while the electron of SOMO in $\mathbf{1}$ and $\mathbf{3}$ is more difficult to be excited. Thus the electron vacancies make the $\mathrm{Co}=\mathrm{O}$ unit possess significant desire for electron and electrophilic attack to the azo bond or naphthalene structure of dyes. ${ }^{57}$ This principle manifested well in the relative degradation efficiency that seemed to depend on the electron nature of the substituents (Fig. 2 and $\mathrm{S} 5 \dagger$ ).

Secondly, the HO-Co ${ }^{\mathrm{III}}$ (opbaX) patterns were also calculated by putting $\mathrm{OH}$ near to the optimized $\left[\mathrm{Co}^{\mathrm{III}} \text { (opbaX) }\right]^{-}$in the same Gaussian 09 program (Fig. 9b). According to the total energy, we chose HO-Co ${ }^{\text {III }}$ (opba) and $\mathrm{HO}-\mathrm{Co}^{\mathrm{III}}\left(\mathrm{opbaCH}_{3}\right)$ models with $S=$ 1 , and $\mathrm{HO}-\mathrm{Co}^{\mathrm{III}}\left(\right.$ opbaNO $\left._{2}\right)$ model with $S=2$ (Table S13†). The different number of spinning electrons should ascribe to the extension effect of $-\mathrm{NO}_{2} \cdot{ }^{58}$ The bond length between Co and $\mathrm{O}$ is around $1.8 \AA$, declaring the single bond between Co and $\mathrm{O}$. Compared with high-valent models, these patterns possess smaller electron spin density distributed around the $\mathrm{O}$ atom $(\sim 0.5)$, leaving near 1 spinning electron delocalized at the bisbenzoamido moiety (Tables S14-S16†) which manifested with the LUMO and SOMO orbitals (Fig. 9b). So the active intermediate can be depicted as $\left[\mathrm{Co}^{\mathrm{III}}-\mathrm{OH}\right]^{\cdot} .^{59}$ Furthermore, the orders of Co-O bond length and orbital energy levels are the same as those of the high-valent models, which can also explain the oxidation power disparity of the three catalysts in contaminant removal. In conclusion, this catalytic system is proposed to proceed with either $\left[\mathrm{Co}^{\mathrm{IV}}=\mathrm{O}^{*}\right]^{-}$or $\left[\mathrm{Co}^{\mathrm{III}}-\mathrm{OH}\right]^{\circ}$ reactive intermediates.

Accordingly, we depicted two generation pathway of reactive intermediates (Scheme 2). As known, the $\mathrm{O}-\mathrm{O}$ bond of hydroperoxides cleaved either heterolytically or homolytically in aqueous, and the tendency of heterolysis was significantly affected by the electronic nature of oxamate complex. ${ }^{21,27}$ When coordinated with electron-withdrawing ligand, center Co was more affine to nucleophilic $\mathrm{OOH}$ moiety because of electron deficiency, which resulted to the rate acceleration in contaminant degradation. ${ }^{\mathbf{6 0}, 61}$ In pathway (a), electronrich cobalt complexes showed a tendency to cleave the hydroperoxide $\mathrm{O}-\mathrm{O}$ bond homolytically, whereas electrondeficient cobalt complexes show a tendency to cleave the

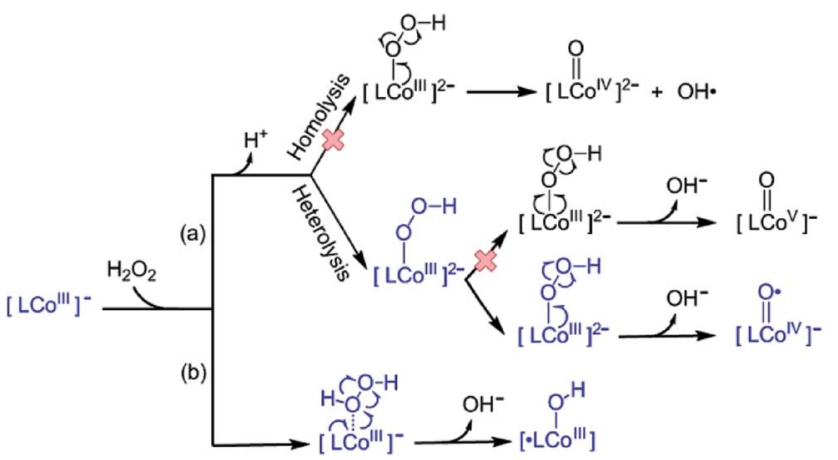

Scheme 2 Proposed pathway and formation of cobalt-oxo electromer $(\mathrm{L}=$ bis-benzoamido). 
heterolytically, in which the tendency was in the order of $2>$ $\mathbf{1}>\mathbf{3}$. Then the $\mathrm{O}-\mathrm{O}$ cleavage followed due to the unstable structure of $-\mathrm{Co}^{\mathrm{III}} \mathrm{OOH}^{2-}$ with formations of $\mathrm{OH}^{-}$and $\mathrm{Co}^{\mathrm{IV}}=$ $\mathrm{O}^{*}$. Notably, this reactive radical was different from the results reported previously by Isabel Fernández et al., who proposed that oxamide cobalt complex played a key role in acetonitrile as $\mathrm{Co}^{\mathrm{IV}}=\mathrm{O}$ structure. ${ }^{22}$ Considering the Gray's "oxo-wall", ${ }^{62}$ the pathway (b) is less exotic, where $\mathrm{Co}-\mathrm{O}_{2} \mathrm{H}_{2}$ broke the $\mathrm{O}-\mathrm{O}$ bond heterolytically and lost $\mathrm{OH}^{-}$, leaving electron deficient $\mathrm{OH}$ moiety. ${ }^{63}$ According to the electron spin density distribution result of $\mathrm{HO}-\mathrm{Co}^{\mathrm{III}}$ (opbaX), $\mathrm{O}$ atom obtained additional 0.5 spinning electron from Co, while the spin of Co did not essentially changed. This meant the bis-benzoamido moiety transferred electron to $\mathrm{Co}$ and Co transferred it to $\mathrm{O}$, thus forming the ligand-based radical intermediate HO$\mathrm{Co}^{\mathrm{III}}$ (opbaX) ${ }^{\circ}$. Electron-withdrawing substituent facilitated the $\mathrm{O}-\mathrm{O}$ bond cleavage, which speeded up the formation of reactive intermediates and the degradation efficiency of pollutants.

\section{Experimental}

\section{Materials and reagents}

The spin-trapping reagent, 5,5-dimethyl-pyrroline-oxide, (DMPO) was obtained from Tokyo Chemical Industry Co., Ltd. $\mathrm{H}_{2} \mathrm{O}_{2}(9.7 \mathrm{M}), m$-chloroperbenzoic acid (mCPBA, 85\%), dyes including AR1, $p$-chlorophenol, and other chemicals used in the syntheses were of analytical grade from commercial suppliers and used as received. Ultrapure water (Millipore Milli-Q Advantage A10 Ultrapure water system) was used throughout the experimental process. The diethyl ester derivatives, 4-nitro$o$-phenylenebis (oxamic acid) $\left(\mathrm{H}_{2} \mathrm{Et}_{2} \mathrm{OpbaNO}_{2}\right)$ and 4-methyl-ophenylenebis (oxamic acid) $\left(\mathrm{H}_{2} \mathrm{Et}_{2} \mathrm{OpbaCH}_{3}\right)$, were synthesized by the corresponding commercially available $o$-phenylenediamine derivatives and ethyloxalyl chloride in tetrahydrofuran by standard condensation techniques in a similar preparation process as the unsubstituted analogue $o$-phenylenebis (oxamic acid) $\left(\mathrm{H}_{2} \mathrm{Et}_{2} \mathrm{Opba}\right)$.

\section{Preparation of catalysts}

The cobalt(III) complexes 1-3 were synthesized according to the steps reported previously. ${ }^{22,64}$ The $\mathrm{Et}_{2} \mathrm{H}_{2} \mathrm{OpbaX}\left(\mathrm{X}=\mathrm{H}, \mathrm{NO}_{2}\right.$, $\mathrm{CH}_{3}$ ) $(5 \mathrm{mmol})$ has been dissolved in a $1: 9$ mixture $(100 \mathrm{~mL})$ of methanol and water, and $50 \mathrm{~mL} \mathrm{NaOH}(21 \mathrm{mmol})$ aqueous solution was added. This resulting mixture was stirred at $70{ }^{\circ} \mathrm{C}$ for $30 \mathrm{~min}$ to facilitate the hydrolysis of the ethyl ester groups. After the temperature of the reaction solution fell to room temperature, $5.0 \mathrm{mmol} \mathrm{Co}\left(\mathrm{NO}_{3}\right)_{2}(50 \mathrm{~mL})$ was added dropwise with vigorous stirring under an oxygen atmosphere for $1 \mathrm{~h}$. The resulting mixture was filtered and concentrated by evaporation of the solvent to about $10 \mathrm{~mL}$, and then cooling in the presence of ethanol to obtain the dark-green product of complex 1 ( $c a$. $1.6 \mathrm{~g}, 80 \%$ yield) after drying under vacuum. Similarly, the brickred complex 2 ( $c a .0 .6 \mathrm{~g}, 30 \%$ yield) and dark-brown complex 3 (ca. $0.5 \mathrm{~g}, 25 \%$ yield) were synthesized respectively except for employing ether in place of ethanol.

\section{Catalytic experiments and analysis}

The typical experimental procedure for the catalytic oxidation of AR1 and $p$-chlorophenol was conducted with complexes 1-3 respectively and carried out in a $40 \mathrm{~mL}$ glass beaker with a magnetic stirrer. The reaction temperature was maintained at $25{ }^{\circ} \mathrm{C}$ or $45^{\circ} \mathrm{C}$ by means of a constant temperature water bath. The initial concentration of AR1 or $p$-chlorophenol in $0.01 \mathrm{M}$ borate buffer was $0.05 \mathrm{mM}$ with $0.02 \mathrm{mM}$ cobalt complex, and then a certain amount of $\mathrm{H}_{2} \mathrm{O}_{2}$ was added to the reaction solution. At given time intervals, a small amount of reaction mixture of AR1 was frequently taken out for observing the concentration changes of substrates, and the concentration of dyes was determined using an ultraviolet-visible (UV-vis) spectrometer (Hitachi U-3010). The concentration changes of $p$ chlorophenol were analyzed by ultra-performance liquid chromatography (UPLC, Acquity BEH C18 column $(1.7 \mu \mathrm{m}, 2.1 \times 50$ $\mathrm{mm})$, Waters). The removal rate was calculated by eqn (1), where $C$ is the concentration of AR1 or $p$-chlorophenol at each reaction time and $C_{0}$ is the initial concentration of the substrate.

$$
\text { Residual rate }=C / C_{0}
$$

Assuming that the initial organic degradation constant fits the data to a pseudo-first-order reaction kinetic model when $\mathrm{H}_{2} \mathrm{O}_{2}$ is in considerable excess, we obtained the apparent rate constant $k_{\text {obs }}$ calculated from the slop of the plot $\ln \left(C / C_{0}\right)$ versus to time.

\section{Characterizations}

The structure and cobalt oxidation state of the cobalt complexes 1-3 in MeCN aqueous solution were characterized by highdefinition mass spectrometry in Q-TOF mode, which were performed on a Synapt G2-S HDMS (Waters) in negative mode equipped with electrospray ionization (ESI) source. The capillary voltage and cone voltage were set at $2.5 \mathrm{kV}$ and $40 \mathrm{~V}$ respectively, and the desolvation gas was set to $900 \mathrm{~L} \mathrm{~h}^{-1}$ at $80{ }^{\circ} \mathrm{C}$. The energies of collision ramp were controlled at $20-40 \mathrm{~V}$ for the MS/MS fragmentation information. The MS data were acquired using the lock spray to ensure mass accuracy and reproducibility with leucineenkephalin ( $\mathrm{m} / \mathrm{z}$ 554.2615) in negative electrospray ionization mode. X-ray photoelectron spectroscopy (XPS) data were recorded on a Thermo Scientific K-Alpha spectrometer (monochromatic Al $\mathrm{K} \alpha, 1486.6 \mathrm{eV}$ ), and the binding energy peaks of the XPS spectra were calibrated by placing the principal C1s binding energy peak at $284.7 \mathrm{eV} .{ }^{1} \mathrm{H}$ NMR spectra were recorded on a Bruker Avance $400 \mathrm{MHz}$ spectrometer. $\mathrm{D}_{2} \mathrm{O}$ was used as solvent and internal standard $\left(\delta_{\mathrm{H}}=4.71\right)$. The EPR signals were detected on a Bruker A300 spectrometer for the free radicals trapped by DMPO at room temperature. The parameter setting typically as follows: center field, $3520 \mathrm{G}$; microwave frequency, $9.77 \mathrm{GHz}$; modulation frequency, $100 \mathrm{kHz}$. We attempted to detect the residual $p$-chlorophenol using UPLC chromatographic separation with a BEH C18 column $(1.7 \mu \mathrm{m}, 2.1 \times 100 \mathrm{~mm})$ using $30 \%$ mobile phases $\mathrm{A}$ (acetonitrile) and $70 \% \mathrm{~B}$ (formic acid/water solution with a volume ratio of $1 / 1000$ ). The flow rate was $0.4 \mathrm{~mL} \mathrm{~min}^{-1}$, and the column oven temperature was set at $30^{\circ} \mathrm{C}$. 


\section{Detection of cobalt-oxo intermediates}

The active intermediates were prepared from $0.02 \mathrm{mM}$ solution of complex 1 in acetonitrile with slight ultrapure water at $-40{ }^{\circ} \mathrm{C}$ (the $\mathrm{pH}$ value was adjusted to 9.5 with ammonia water previously) using 2 equivalents of $m$ CPBA (85\%), and the solution was infused directly into ion source of high-definition mass spectrometry with a syringe manually. In addition, to determine active intermediates, the source temperature was set at $40{ }^{\circ} \mathrm{C}$ to minimize the decomposition of intermediate species.

\section{Conclusions}

Nature has developed various metalloenzymes such as hemecontaining horseradish peroxidase and cytochrome P450; they are capable of stubborn substrate transformations. So there has long been significant interest in modelling such enzyme active sites and developing biomimetic catalysts for various purposes. Based on the same $\mathrm{Fe}^{\mathrm{IV}}$ active species yet with different catalytic ability, here we designed $\left[\mathrm{Co}^{\mathrm{III}}(\mathrm{opbaX})\right]^{-} / \mathrm{H}_{2} \mathrm{O}_{2}$ system which exhibited excellent catalytic performance in oxidizing targeted pollutants such as dyes and $p$-chlorophenol via non-hydroxyl radical process pathway under high backgrounds of constituents. The electron-drawing substituents have been proved to positively promote the $\mathrm{H}_{2} \mathrm{O}_{2}$ activation while electron-donating substituents were proved negatively. The results of radical trapping experiments and DFT calculations described $\left[\mathrm{Co}^{\mathrm{IV}}=\right.$ $\left.\mathrm{O}^{*}\right]^{-}$and $\left[\mathrm{Co}^{\mathrm{III}}-\mathrm{OH}\right]^{\cdot}$ intermediates, which played as the key species in this oxidation processes. Accordingly, electronwithdrawing substituent enhanced the oxidizing power of $\left[\mathrm{Co}^{\mathrm{III}}(\mathrm{opbaX})\right]^{-}$due to the electron environment change on cobalt-oxo moiety. This contribution provided further evidence for the formation of high-valent cobalt-oxo radical species, which are akin to the oxoiron(Iv) complex proposed as the actual oxidant in the families of P450 and HRP. Meanwhile, future studies need to give more direct evidence and illumination of $\left[\mathrm{Co}^{\mathrm{III}}-\mathrm{OH}\right]^{\cdot}$ and $\left[\mathrm{Co}^{\mathrm{IV}}=\mathrm{O}^{\cdot}\right]^{-}$in catalysis.

\section{Conflicts of interest}

There are no conflicts of interest to declare.

\section{Acknowledgements}

This work was supported by the National Natural Science Foundation of China (No. 51703201), and Zhejiang Provincial Natural Science Foundation of China (No. LQ17E030003).

\section{Notes and references}

1 M. Šimšíková, M. Bartoš, J. Čechal and T. Šikola, Catal. Sci. Technol., 2016, 6, 3008-3017.

2 D. Chatterjee, S. Rothbart and R. van Eldik, RSC Adv., 2013, 3, 3606.

3 S. Bhattacharya, S. Bala and R. Mondal, RSC Adv., 2016, 6, 25149-25158.
4 S. Sengupta and R. Mondal, J. Mater. Chem. A, 2014, 2, 1637316377.

5 L. Xie, L. Zhou, T. Liu and X. Xu, RSC Adv., 2016, 6, 106935106944.

6 A. Y. Satoh, J. E. Trosko and S. J. Masten, Environ. Sci. Technol., 2007, 41, 2881-2887.

7 W. Huang, M. Brigante, F. Wu, C. Mousty, K. Hanna and G. Mailhot, Environ. Sci. Technol., 2013, 47, 1952-1959.

8 X. Li, C. Chen and J. Zhao, Langmuir, 2001, 17, 4118-4122.

9 X. Zhou, J. Lan, G. Liu, K. Deng, Y. Yang, G. Nie, J. Yu and L. Zhi, Angew. Chem., 2012, 124, 182-186.

10 N. Guo, Y. Cao, Y. Rong and D. Jia, RSC Adv., 2016, 6, 106046106053.

11 E. M. Siedlecka, A. Więckowska and P. Stepnowski, J. Hazard. Mater., 2007, 147, 497-502.

12 H. Kim, W. Kim, Y. Mackeyev, G.-S. Lee, H.-J. Kim, T. Tachikawa, S. Hong, S. Lee, J. Kim and L. J. Wilson, Environ. Sci. Technol., 2012, 46, 9606-9613.

13 S. G. Sligar, Science, 2010, 330, 924.

14 P. R. O. De Montellano, Cytochrome P450: Structure, Mechanism, and Biochemistry, Springer Science \& Business Media, 2005.

15 N. C. Veitch, Phytochemistry, 2004, 65, 249-259.

16 B. L. Allen, G. P. Kotchey, Y. Chen, N. V. Yanamala, J. KleinSeetharaman, V. E. Kagan and A. Star, J. Am. Chem. Soc., 2009, 131, 17194-17205.

17 J. Rittle and M. T. Green, Science, 2010, 330, 933-937.

18 J. Bennett, Y. A. Miah, D. S. Varsani, E. Salvadori and T. S. Sheriff, RSC Adv., 2016, 6, 103372-103381.

19 T. S. Sheriff, M. Watkinson, M. Motevalli and J. F. Lesin, Dalton Trans., 2010, 39, 53-55.

20 S. Y. Shaban and R. van Eldik, Dalton Trans., 2011, 40, 287294.

21 W. Nam, H. J. Han, S.-Y. Oh, Y. J. Lee, M.-H. Choi, S.-Y. Han, C. Kim, S. K. Woo and W. Shin, J. Am. Chem. Soc., 2000, 122, 8677-8684.

22 I. Fernández, J. R. Pedro, A. L. Roselló, R. Ruiz, I. Castro, X. Ottenwaelder and Y. Journaux, Eur. J. Org. Chem., 2001, 2001, 1235-1247.

23 J. Estrada, I. Fernández, J. Pedro, X. Ottenwaelder, R. Ruiz and Y. Journaux, Tetrahedron Lett., 1997, 38, 2377-2380.

24 N. A. Stephenson and A. T. Bell, J. Mol. Catal. A: Chem., 2007, 275, 54-62.

25 K. Auclair, P. Moënne-Loccoz and P. R. Ortiz de Montellano, J. Am. Chem. Soc., 2001, 123, 4877-4885.

26 D. S. Salnikov, R. Silaghi-Dumitrescu, S. V. Makarov, R. van Eldik and G. R. Boss, Dalton Trans., 2011, 40, 9831-9834.

27 N. Li, W. Lu, K. Pei, Y. Yao and W. Chen, Appl. Catal., B, 2015, 163, 105-112.

28 N. Li, W. Lu, K. Pei, Y. Yao and W. Chen, ACS Appl. Mater. Interfaces, 2014, 6, 5869-5876.

29 L. I. Rodionova, A. V. Smirnov, N. E. Borisova, V. N. Khrustalev, A. A. Moiseeva and W. Grünert, Inorg. Chim. Acta, 2012, 392, 221-228. 
30 T. Ivanova, A. Naumkin, A. Sidorov, I. Eremenko and M. Kiskin, J. Electron Spectrosc. Relat. Phenom., 2007, 156, 200-203.

31 A. Mederos, S. Domínguez, R. Hernández-Molina, J. n. Sanchiz and F. Brito, Coord. Chem. Rev., 1999, 193, 857-911.

32 R. Ruiz, C. Surville-Barland, A. Aukauloo, E. AnxolabehereMallart, Y. Journaux, J. Cano and M. C. Muñoz, J. Chem. Soc., Dalton Trans., 1997, 745-752.

33 S. K. Sharma and R. Gupta, Inorg. Chim. Acta, 2011, 376, 95104.

34 W. C. Ellis, C. T. Tran, R. Roy, M. Rusten, A. Fischer, A. D. Ryabov, B. Blumberg and T. J. Collins, J. Am. Chem. Soc., 2010, 132, 9774-9781.

35 T. G. Traylor, C. Kim, J. L. Richards, F. Xu and C. L. Perrin, J. Am. Chem. Soc., 1995, 117, 3468-3474.

36 S. Roeser, F. Bozoglian, C. J. Richmond, A. B. League, M. Z. Ertem, L. Francàs, P. Miró, J. Benet-Buchholz, C. J. Cramer and A. Llobet, Catal. Sci. Technol., 2016, 6, 5088-5101.

37 S. Kundu, A. Chanda, J. V. Thompson, G. Diabes, S. K. Khetan, A. D. Ryabov and T. J. Collins, Catal. Sci. Technol., 2015, 5, 1775-1782.

38 A. Anushree, S. Kumar and C. Sharma, Catal. Sci. Technol., 2016, 6, 2101-2111.

39 J. Chen and L. Zhu, Catal. Today, 2007, 126, 463-470.

40 W. Lu, N. Li, S. Bao, W. Chen and Y. Yao, Carbon, 2011, 49, 1699-1709.

41 M. Kasiri, H. Aleboyeh and A. Aleboyeh, Appl. Catal., B, 2008, 84, 9-15.

42 S.-P. Sun, C.-J. Li, J.-H. Sun, S.-H. Shi, M.-H. Fan and Q. Zhou, J. Hazard. Mater., 2009, 161, 1052-1057.

43 H. Ghodbane and O. Hamdaoui, Chem. Eng. J., 2010, 160, 226-231.

44 J. Kiwi, A. Lopez and V. Nadtochenko, Environ. Sci. Technol., 2000, 34, 2162-2168.

45 D. Lawless, N. Serpone and D. Meisel, J. Phys. Chem., 1991, 95, 5166-5170.

46 L. Wang, M. Cao, Z. Ai and L. Zhang, Environ. Sci. Technol., 2014, 48, 3354-3362.
47 J. Sheng, X. Li and Y. Xu, ACS Catal., 2014, 4, 732-737.

48 M. R. Bukowski, K. D. Koehntop, A. Stubna, E. L. Bominaar, J. A. Halfen, E. Münck, W. Nam and L. Que, Science, 2005, 310, 1000-1002.

49 F. T. De Oliveira, A. Chanda, D. Banerjee, X. Shan, S. Mondal, L. Que, E. L. Bominaar, E. Münck and T. J. Collins, Science, 2007, 315, 835-838.

50 C. Lee, W. Yang and R. G. Parr, Phys. Rev. B: Condens. Matter Mater. Phys., 1988, 37, 785.

51 S. Ozaki, H. Mimura, N. Yasuhara, M. Masui, Y. Yamagata, K. Tomita and T. J. Collins, J. Chem. Soc., Perkin Trans. 2, 1990, 353-360.

52 C.-G. Liu, Z.-M. Su, W. Guan and L.-K. Yan, Inorg. Chem., 2008, 48, 541-548.

53 Y. Wang, D. Janardanan, D. Usharani, K. Han, L. Que Jr and S. Shaik, ACS Catal., 2013, 3, 1334-1341.

54 S. Vosko, L. Wilk and M. Nusair, Can. J. Phys., 1980, 58, 12001211.

55 R. A. Eikey and M. M. Abu-Omar, Coord. Chem. Rev., 2003, 243, 83-124.

56 R. Arumugaperumal, V. Srinivasadesikan, M.-C. Lin, M. Shellaiah, T. Shukla and H.-C. Lin, RSC Adv., 2016, 6, 106631-106640.

57 H. Zhao and F. o. P. Gabbaï, Organometallics, 2012, 31, 23272335.

58 R. Flores, A. E. Torres and S. Fomine, RSC Adv., 2016, 6, 64285-64296.

59 G. I. Berglund, G. H. Carlsson, A. T. Smith, H. Szöke, A. Henriksen and J. Hajdu, Nature, 2002, 417, 463-468.

60 W. Y. Tcho, B. Wang, Y. M. Lee, K. B. Cho, J. Shearer and W. Nam, Dalton Trans., 2016, 45, 14511-14515.

61 D. Chatterjee, S. Rothbart and R. van Eldik, Dalton Trans., 2013, 42, 4725-4729.

62 J. R. Winkler and H. B. Gray, Struct. Bonding, 2012, 142, 1728.

63 A. I. Nguyen, R. G. Hadt, E. I. Solomon and T. D. Tilley, Chem. Sci., 2014, 5, 2874-2878.

64 H. O. Stumpf, Y. Pei, O. Kahn, J. Sletten and J. P. Renard, J. Am. Chem. Soc., 1993, 115, 6738-6745. 